\title{
THE RELATIONSHIP BETWEEN DISSOLVED SOLIDS YIELD AND THE PRESENCE OF SNOW COVER IN THE PERIGLACIAL BASIN OF THE OBRUCHEV GLACIER (POLAR URALS) DURING THE ABLATION SEASON
}

\author{
ŁUKASZ STACHNIK \\ Jagiellonian University, Institute of Geography and Spatial Management, Kraków, Poland \\ ŁUKASZ UZAROWICZ \\ Warsaw University of Technology, Faculty of Geodesy and Cartography, Warszawa, Poland. \\ Manuscript received: November 20, 2010 \\ Revised version: February 21, 2011
}

\begin{abstract}
STACHNik Ł., Uzarowicz Ł., 2011. The relationship between dissolved solids yield and the presence of snow cover in the periglacial basin of the Obruchev Glacier (Polar Urals) during the ablation season. Quaestiones Geographicae 30(1), Bogucki Wydawnictwo Naukowe, Poznań, pp. 95-103, 5 Figs., 1 Tab. ISBN 978-83-62662-39-5. ISSN 0137477X. DOI 10.2478/v10117-011-0009-x.
\end{abstract}

Aвstract. Hydrochemical investigations were carried out in the periglacial basin of Obruchev Glacier (Polar Urals, Russia) in order to provide a quantitative and qualitative comparison of dissolved solids yields during the ablation season with and without snow cover taking into account the mineral composition of rocks and deposits occurring in the studied area. The concentration of dissolved solids in the waters of the investigated basin is very

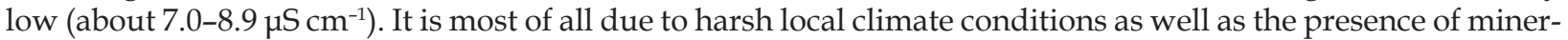
als resistant to weathering in the parent material. Both factors contribute to the low rate of chemical weathering in the area. Results obtained indicate that a larger dissolved solids yield was transported during the period with snow cover $\left(106 \mathrm{~kg} \mathrm{~km}^{-2} \mathrm{day}^{-1}\right.$, on average), than at the same time of the year but without snow cover $\left(13 \mathrm{~kg} \mathrm{~km}{ }^{-2}\right.$ $\mathrm{day}^{-1}$, on average) indicating that melting snow is an important factor influencing the yield of dissolved solids in surface waters.

KeYwords: Polar Urals, Obruchev Glacier, solute yield, periglacial basin, ablation season

Łukasz Stachnik, Institute of Geography and Spatial Management, Jagiellonian University, ul. Gronostajowa 7, 30-387 Kraków, Poland, e-mail: l.stachnik@uj.edu.pl

\section{Introduction}

The amount of dissolved solids transported by waters is a measure of the degree of chemical denudation in a drainage basin. It can be used to determine the intensity and qualitative diversity of chemical denudation processes. The studies (e.g. Rapp 1960, Dixon et al. 1984, Caine 1992, Beylich et al. 2006) have shown that chemical denudation is more important than mechanical denudation in periglacial basins, unlike e.g. glacial basins in which mechanical denudation predominate. 
A key factor that affects the degree of chemical denudation is the depth and duration of snow cover (Caine 1992). Caine (1992) research in the Rocky Mountains has shown that thick patches of snow, which cover less than $10 \%$ of a basin's total area, are capable of generating a dissolved solids yield corresponding to $60 \%$ of total chemical denudation. In addition, increased snow cover duration was capable of producing a fourfold rate of chemical denudation (Caine 1979).

Contemporary hydrochemical research in polar and alpine regions tend to focus primarily on glaciated basins (Collins 1979, Tranter et al. 1996, Wadham et al. 1998, Hodson et al. 2000, Wadham et al. 2000, Brown 2002). It has been shown that chemical denudation processes proceed at different rates during the ablation season, which depends on the degree of subglacial drainage, delivery of suspended matter, and chemical denudation in proglacial areas. The hydrochemical properties of periglacial basins, however, have not received as much attention (Caine 1992, Darmody et al. 2000, Beylich et al. 2004).

The purpose of this paper is to provide a quantitative and qualitative comparison of dissolved solids yields during the ablation season with and without snow cover in a selected periglacial basin in the Polar Ural Mountains in Russia.

\section{Study area}

The study area is located in the Polar Urals (Russia) in the vicinity of Chadata Jugan-Lor Lake (Fig. 1). The basin stretches from the east to the west. The western part includes the Obruchev



Fig. 1. Study area 
Glacier, which is situated in a east facing cirque. The basin is $12.83 \mathrm{~km}^{2}$ in area and the glacier occupies about $2 \%$ of it. The study area is characterized by changes in elevation up to $900 \mathrm{~m}$. The depth of snow cover varies across the study area, as well as across the Polar Urals in general, ranging from $0.5 \mathrm{~m}$ in open areas to $50 \mathrm{~m}$ in cirques facing to the east (Tushinkiy 1963).

Air temperature and humidity data were measured during the study period at a location representative of the tundra region. Period with snow cover (the summer 2008) was characterized by higher daily mean air temperature $\left(15.5^{\circ} \mathrm{C}\right.$ on average; from $9.1^{\circ} \mathrm{C}$ to $18.8^{\circ} \mathrm{C}$ ) in comparison with the period without snow cover (the summer $2007,10.0^{\circ} \mathrm{C}$ on average; from $4.9^{\circ} \mathrm{C}$ to $19.7^{\circ} \mathrm{C}$ ). Air humidity was higher during period with no snow cover $(80.5 \%)$ versus period with snow cover $(69.1 \%)$ (P. Wałach - personal comm.). Air temperatures for the entire study period were similar to average air temperatures measured in July and August (1958-1980) in the Lake Chadata-JuganLor meteorological station (O. Solomina, written communication December 2006 in: Mangerud et al. 2008). Airflow during period with snow cover and without snow cover was from the south and north sectors, respectively (Wałach 2008).

In addition, mass balance surveys were carried out at Obruchev Glacier for the period between 1958 and 1980. This research showed considerable negative cumulative specific mass balance (c.a. -3.2 $\mathrm{m}$ for period 1958-1981) with high inter-annual variations (Voloshina 1987). It was associated with terminus retreat $(135 \mathrm{~m})$ and decreasing of glacier area from $0.36 \mathrm{~km}^{2}$ in 1953 to $0.21 \mathrm{~km}^{2}$ in 2000 (Kononov et al. 2005). The Obruchev Glacier is located ca. $800 \mathrm{~m}$ below the present-day climatic snow line and accumulation pattern is strongly dependent on snowdrift to the cirque (Troitsky 1961).

The study area is located in a Mid-Ural geologic zone formed primarily of Paleozoic metamorphic rocks (Stupnicka 1978).

\section{Methods}

Water samples were collected at the tip of the Obruchev glacier basin. Discharge rates as well as physical and chemical properties of waters were determined. The research was performed during the ablation season (summer) during the following two periods: 1 ) with snow cover - July 11, 2008 to August 2, 2008, and 2) without snow cover - August 2, 2007 to August 20, 2007. Discharge rates were determined via the propellertype current meter and the surface float. The former method utilized speeds at 0.4 water depth measured at five hydrometric verticals. The data obtained was then used to calculate discharge rates.

High water levels in 2008 made it impossible to use the propeller-type current meter to measure flow speed, and, therefore, the surface float was used instead. Discharge rates were determined based on an average of five surface velocity measurements multiplied by a reduction coefficient $(\mathrm{a}=0.84)$. The obtained water level and water speed data were used to construct rating curves for two separate periods.

An ELMETRON CC-315 conductometer was used to measure water temperature and specific electrical conductivity (SEC). Water samples were filtered using membrane filters $(0.45 \mu \mathrm{m})$ and Sartorius filtration kits, and finally placed in $0.5 \mathrm{dm}^{3}$ PET bottles. The filtered water samples were kept in a dark place at temperatures below $4^{\circ} \mathrm{C}$.

An ICS-2000 DIONEX ion chromatograph was used to analyze the chemical composition of the collected water samples. The analyses were carried out at the Hydrochemical Laboratory of the Institute of Geography and Spatial Management at the Jagiellonian University in Kraków. No meaningful differences were detected between in situ SEC measurements and SEC measurements made in the laboratory.

Total mineral content was determined based on the relationship between dissolved solids concentration (in $\mathrm{mg} \mathrm{dm}^{-3}$ ) and electrical conductivity measured in situ (Darmody et al. 2000). Daily dissolved solids yield was then calculated based on average daily mineral content and corresponding discharge rates. Hydrochemical data was used to determine key chemical weathering characteristics (Hounslow 1995).

The petrographic properties of rocks found in the investigated area were determined macroscopically and microscopically. The mineral composition of rocks and their saprolites was determined using X-ray diffraction (XRD). The sam- 
ple rocks and deposits were ground before testing. The analyses were performed using Philips X'Pert diffractometer with the generator PW1870 and the vertical goniometer PW3020, equipped with a $1^{\circ}$ divergence slit, $0.2 \mathrm{~mm}$ receiving slit, incident- and diffracted-beam Soller slits, $1^{\circ}$ anti scatter slit, and a graphite diffracted-beam monochromator. $\mathrm{CuK} \alpha$ radiation was used with the applied voltage of $40 \mathrm{kV}$ and $30 \mathrm{~mA}$ current. Random mounts of the bulk material were scanned from 2 to $64^{\circ} 2 \Theta$ at a counting time of 1 second per $0.02^{\circ}$ step. The analyses were performed at the laboratory of the Institute of Geological Sciences, Jagiellonian University, Kraków, Poland.

\section{Results}

\section{Mineral composition of the parent material}

Metamorphic rocks (phyllite, chlorite schist, sericite schist, and rarely gneiss) are the predomi- nant components of the parent material across the study area. They mainly consist of silicate minerals such as micas (mainly muscovite: $\mathrm{KAl}_{2}\left(\mathrm{Si}_{3} \mathrm{Al}\right)$ $\mathrm{O}_{10}(\mathrm{OH}, \mathrm{F})_{2}$ as well as small amounts of paragonite: $\left.\mathrm{NaAl}_{2}\left(\mathrm{Si}_{3} \mathrm{Al}\right) \mathrm{O}_{10}(\mathrm{OH})_{2}\right)$, quartz $\left(\mathrm{SiO}_{2}\right)$, chlorite $\left(\mathrm{Mg}, \mathrm{Fe}^{2+}\right)_{5} \mathrm{Al}\left[\mathrm{AlSi}_{3} \mathrm{O}_{10}(\mathrm{OH})_{8}\right]$, and feldspars. The latter are represented by plagioclases $(\mathrm{Na}$ and $\mathrm{Ca}$ feldspars), with albite $\mathrm{Na}\left[\mathrm{AlSi}_{3} \mathrm{O}_{8}\right]$ being the main constituent. Ca-plagioclase (anorthite) is most likely not present, as indicated by a lack of typical reflections in the XRD patterns. Feldspars are also represented by a small amount of K-feldspar K[AlSi ${ }_{3} \mathrm{O}_{8}$ ]. The deposits collected from the foreground of the Obruchev Glacier are characterized by a similar mineral composition as rock samples (Fig. 2).

Few calcium-bearing minerals were found in the study area. Epidote $\mathrm{Ca}_{2}\left(\mathrm{Al}, \mathrm{Fe}^{3+}\right)\left[\mathrm{O}|\mathrm{OH}| \mathrm{SiO}_{4} \mid \mathrm{Si}_{2} \mathrm{O}_{7}\right]$ was found occasionally in some rock veins. Plagioclases may contain trace amounts of calcium (Fig. 2). While the rocks investigated did not contain calcium plagioclases, the sodium plagioclases

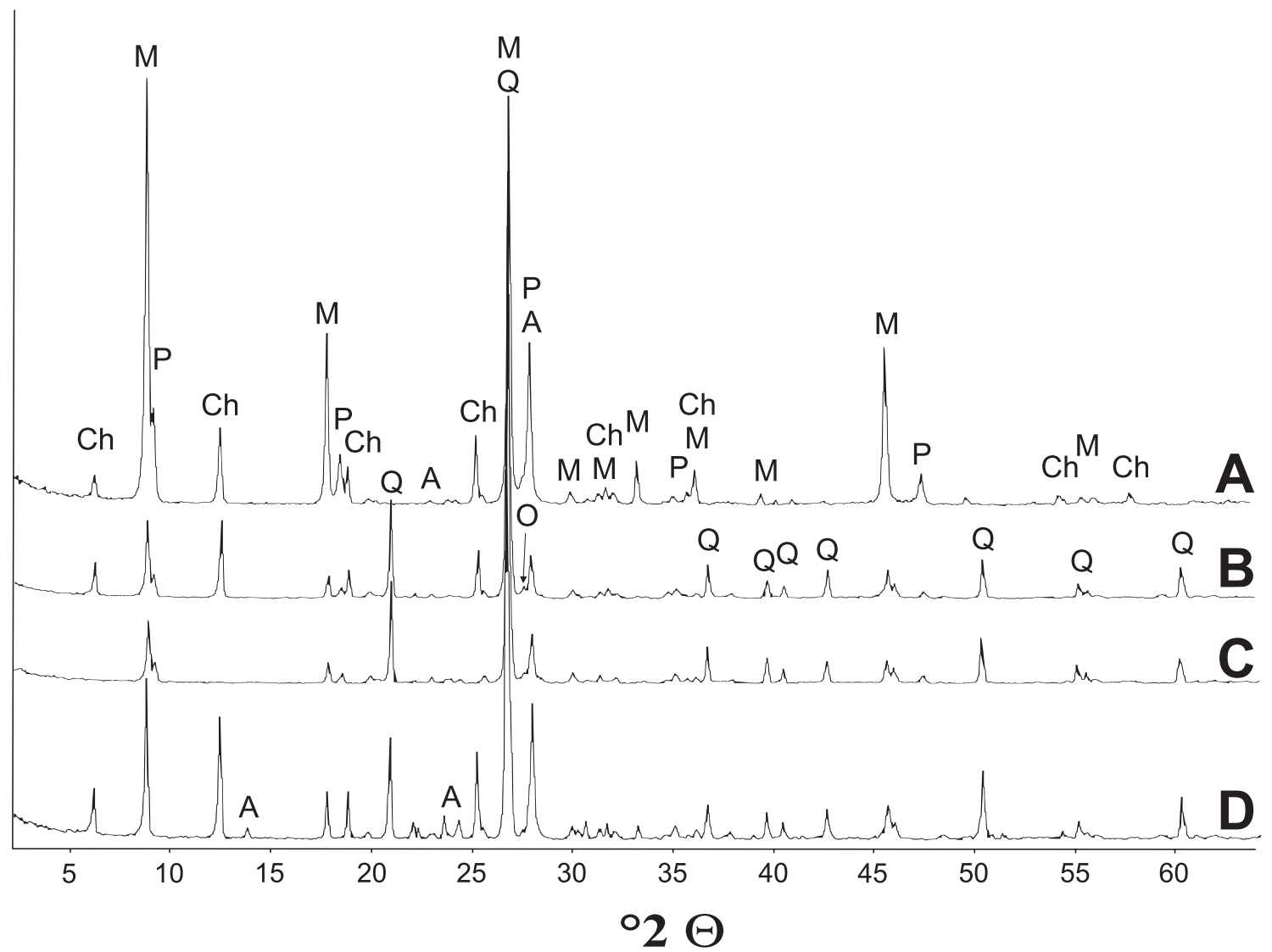

Fig. 2. Mineral composition of rocks and deposits from Obruchev Glacier basin based on XRD; A) phyllit, B) sericitic-chlorite schist, C) mica schist, D) fluvioglacial deposits from Obruchev Glacier foreland

Minerals: A - plagioklaz (probably albite), $\mathrm{Ch}$ - chlorite, $\mathrm{M}$ - muscovit, $\mathrm{O}$ - potassium feldspar (probably orthoclase), $\mathrm{P}$ - paragonite, $\mathrm{Q}$ - quartz. 
found across the study area may contain trace amounts of calcium (Bolewski 1982).

\section{Hydrology and hydrochemistry of the surface waters}

The discharge rate during the period with snow cover ( $2656 \mathrm{dm}^{-3} \mathrm{~s}^{-1}$ on average) was ten times greater than that during the period with no snow cover (263 $\mathrm{dm}^{-3} \mathrm{~s}^{-1}$ on average); (Fig. 3). The period with snow cover was characterized by well-defined cycles and significant daily fluctuations. High rates of discharge during the pe- riod with snow cover were mainly the result of snow melting with negligible precipitation input (Wałach \& Stachnik 2011).

During the period with snow cover, the dissolved solids yield was $106 \mathrm{~kg} / \mathrm{km}^{-2} \mathrm{day}^{-1}$, on average, and ranged from 41 to $165 \mathrm{~kg} \mathrm{~km}^{-2}$ day $^{-1}$ ). During periods with no snow cover, the dissolved solids yield was $13 \mathrm{~kg} \mathrm{~km}^{-2}$ day $^{-1}$, on average, and ranged from 8 to $37 \mathrm{~kg} \mathrm{~km}^{-2}$ day $^{-1}$ ); (Fig 3). Electrical conductivity was at an average of $7.0 \mu \mathrm{S} \mathrm{cm}^{-1}$ during the period with snow cover, which was lower than during the period with no snow cover (8.9 $\mathrm{\mu S} \mathrm{cm}^{-1}$, on average); (Fig. 4). Daily variations of electrical conductivity were observed,
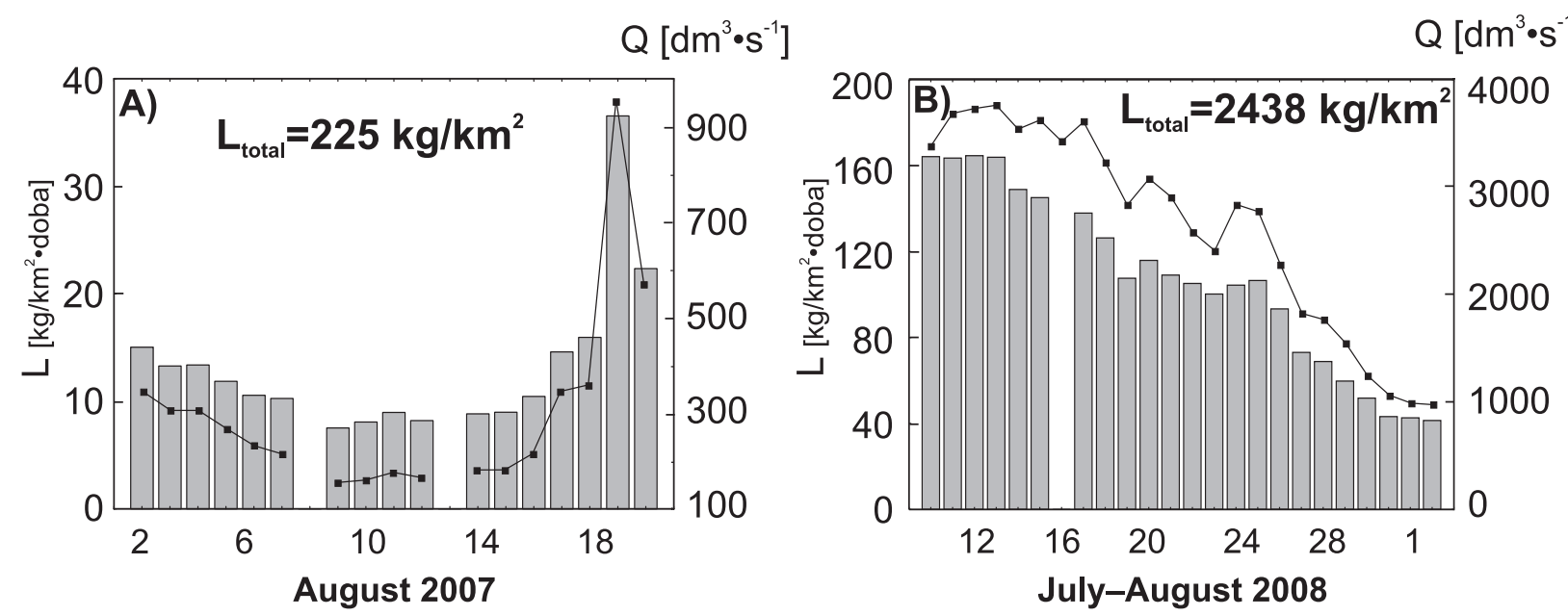

Fig. 3. Mean diurnal discharge $\left[\mathrm{dm}^{3} \mathrm{~s}^{-1}\right]$ and diurnal dissolved solid yields at the Obruchev Glacier gauging station during period of: A) snow cover absence , B) snow coverage
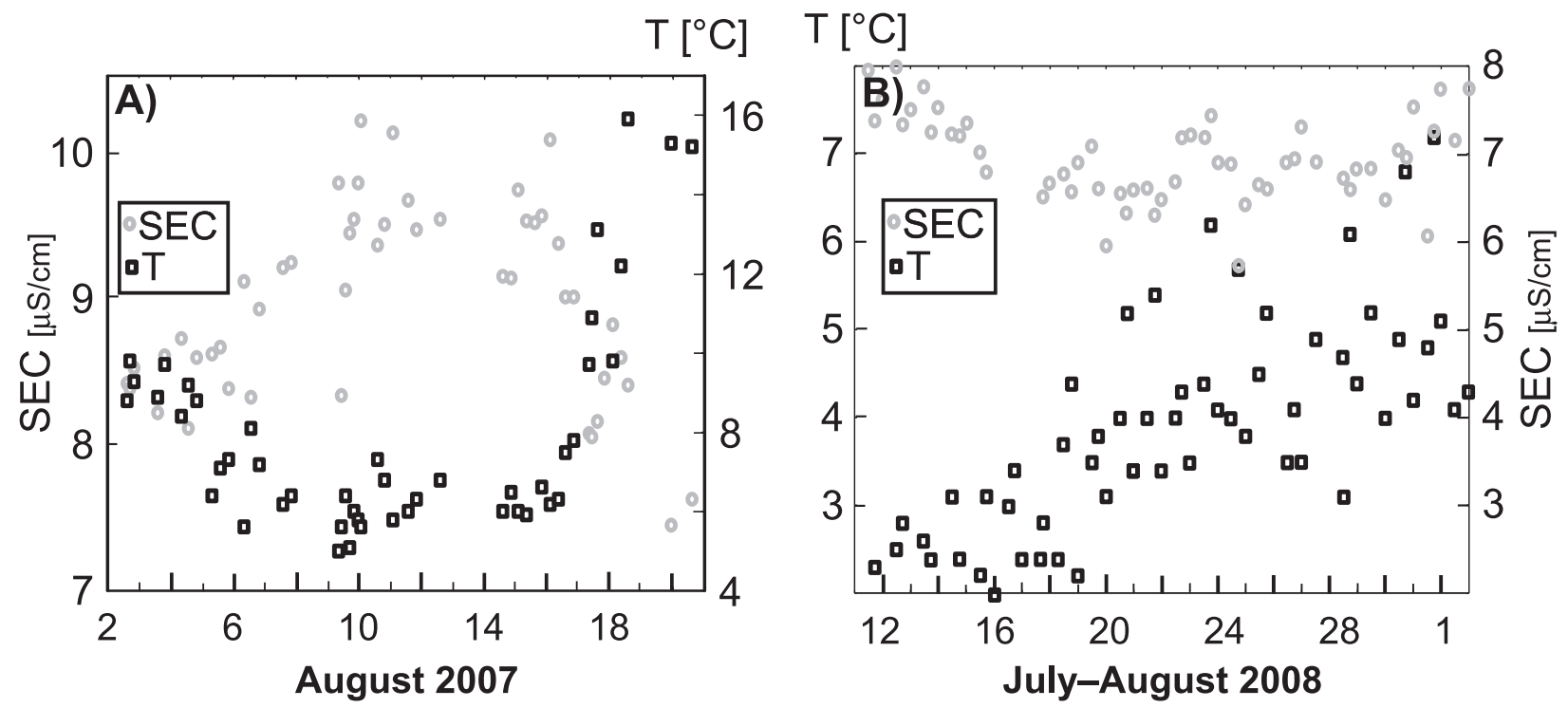

Fig. 4. Water temperature and SEC of water at the Obruchev Glacier gauging station during period of: A) snow cover absence, B) snow coverage 
with maxima occurring during periods of lowest discharge and minima during periods of highest discharge. The concentration of dissolved solids in the water samples collected was very low for both study periods.

The following two ions dominated the mineral content of the water samples both during the period with snow cover and the period without snow cover: $\mathrm{Ca}^{2+}\left(1.27 \mathrm{mg} \mathrm{dm}^{-3}\right.$, on average) and $\mathrm{HCO}_{3}^{-}$(3.37 $\mathrm{mg} \mathrm{dm}^{-3}$, on average). Moderate concentrations of the following ions were detected: $\mathrm{SO}_{4}^{2-}\left(0.74 \mathrm{mg} \mathrm{dm}{ }^{-3}\right.$, on average $), \mathrm{Na}^{+}$ (0.51 $\mathrm{mg} \mathrm{dm}^{-3}$, on average), $\mathrm{NO}_{3}^{-}\left(0.34 \mathrm{mg} \mathrm{dm}^{-3}\right.$, on average), $\mathrm{Cl}^{-}\left(0.32 \mathrm{mg} \mathrm{dm}^{-3}\right.$, on average). Trace amounts of the remaining ions were detected and their concentration order was as follows: $\mathrm{K}^{+}>\mathrm{Mg}^{2+}>\mathrm{NH}_{4}^{+}>\mathrm{F}^{-}>\mathrm{NO}_{2}^{-}$. The $\mathrm{PO}_{4}^{3-}$ ion was below the detection limit.

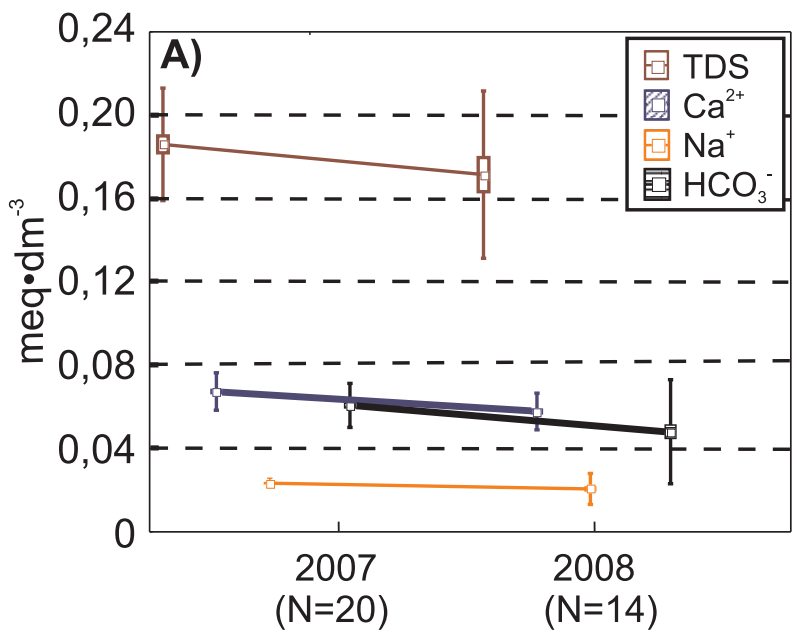

The concentration of most of the investigated ions in water was lower during the period with snow cover versus the period without snow cover. The calcium, $\mathrm{Na}^{+}, \mathrm{NH}_{4}^{+}$, and $\mathrm{HCO}_{3}^{-}$concentrations (meq $\mathrm{dm}^{-3}$ ) were lower relative to the period without snow by $14 \%, 12 \%, 43 \%$, and $25 \%$, respectively. $\mathrm{Cl}^{-}$concentration, on the other hand, was 22\% higher in the former period (Fig. 5). The concentration of $\mathrm{F}^{-}$was found to be above the detection limit during the period without snow cover and below the detection limit during the period with snow cover.

Most indices of chemical weathering did not vary substantially over the course of the two study periods. Langelier Saturation Index (LSI) values show that surface waters were significantly undersaturated with respect to calcite. The value of the $\mathrm{Na} /(\mathrm{Na}+\mathrm{Cl})$ index underscores the

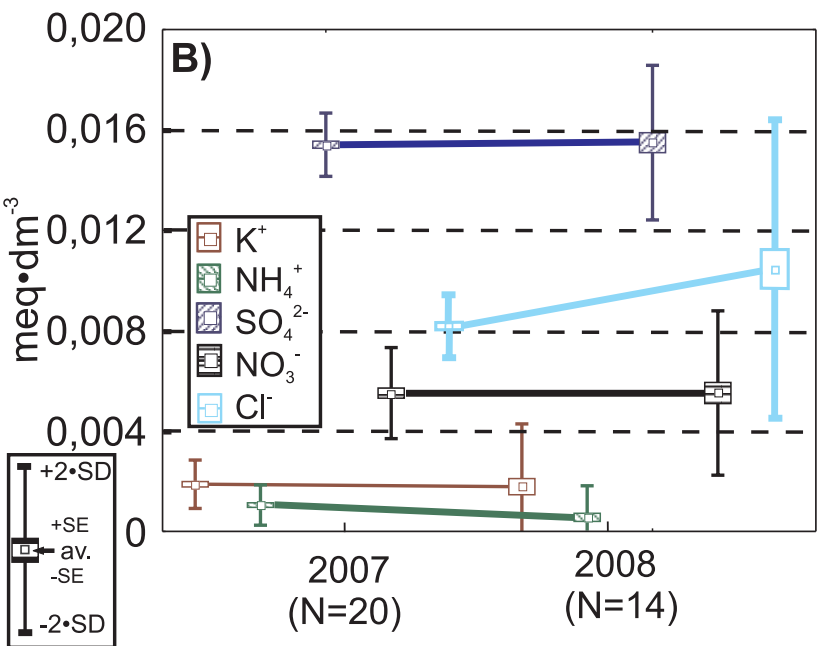

Fig. 5. Comparison of water chemistry at the Obruchev Glacier gauging station from periods of snow cover absence (2007) and with snow coverage (2008)

Table 1. Source rock deductions based on water chemistry from Obruchev Glacier gauging station (Hounslow, 1995)

\begin{tabular}{|c|c|c|c|c|c|}
\hline \multirow{2}{*}{ Weathering Indicator } & \multicolumn{2}{|r|}{2008} & \multicolumn{2}{|r|}{2007} & \multirow{2}{*}{ Interpretation } \\
\hline & & Average; $\mathbf{N}$ & & Average; $\mathbf{N}$ & \\
\hline $\begin{array}{l}\text { Langelier Saturation Index } \\
\text { (LSI) }\end{array}$ & $<0$ & $-6.28 ; 14$ & $<0$ & $-6.16 ; 19^{*}$ & $\begin{array}{c}\text { Significantly undersaturaed with respect to } \\
\text { calcite }\end{array}$ \\
\hline $\mathrm{Na}^{+} / \mathrm{Na}^{+}+\mathrm{Cl}^{-}$ & $>0,5$ & $0.66 ; 14$ & $>0,5$ & $0.74 ; 20$ & Ion exchange \\
\hline $\mathrm{Ca}^{2+} / \mathrm{Ca}^{2+}+\mathrm{SO}_{4}^{2-}$ & $>0,5$ & $0.79 ; 14$ & $>0,5$ & $0.81 ; 20$ & $\begin{array}{l}\text { Calcium source other than Gypsum - carbon- } \\
\text { ates or silicate }\end{array}$ \\
\hline \multirow{2}{*}{$\mathrm{Na}^{+}+\mathrm{K}^{+}-\mathrm{Cl}^{-} / \mathrm{Na}^{+}+\mathrm{K}^{+}-\mathrm{Cl}^{-}+\mathrm{Ca}^{2+}$} & $>0,2$ & $0.236 ; 1$ & $>0,2$ & $0.21 ; 9$ & Plagioclase likely \\
\hline & $<0,2$ & $0.163 ; 13$ & $<0,2$ & $0.197 ; 11$ & Plagioklase unlikely \\
\hline $\mathrm{Cl}^{-}$/sum of anions & $<0,8$ & $0.14 ; 14$ & $<0,8$ & $0.092 ; 20$ & Rock weathering \\
\hline $\mathrm{HCO}_{3}^{-} /$sum of anions & $<0,8$ & 0,$59 ; 14$ & $<0,8$ & 0,$67 ; 20$ & \multirow{2}{*}{ Rainwater } \\
\hline \multicolumn{5}{|c|}{ generaly low sulphate } & \\
\hline
\end{tabular}

* - lack of one measurement of water temperature caused lack of one calculation of Langelier Saturation Index (LSI). 
significance of ion exchange as a means of releasing $\mathrm{Na}+$ into aqueous solutions. The value of this index was lower during the period with snow cover, which was related with increased atmospheric precipitation. The $\mathrm{Ca} /\left(\mathrm{Ca}+\mathrm{SO}_{4}\right)$ index did not vary significantly between the two study periods and suggests that the calcium must come from a source other than gypsum (Tab. 1).

The $(\mathrm{Na}+\mathrm{K}-\mathrm{Cl}) /(\mathrm{Na}+\mathrm{K}-\mathrm{Cl}+\mathrm{Ca})$ index varies significantly between both study periods. This index suggests that plagioclase weathering was more likely during periods without snow cover. The $\mathrm{Cl} /$ sum-of-anions index indicates that the chemical composition of the collected water samples is more likely the result of chemical weathering than precipitation. It must be noted that the value of this index was more than 1.5 times greater for the period with snow cover (Table 1). However, the value of the $\mathrm{HCO}_{3} /$ sum-of-anions index suggests that the chemical composition of the collected water samples may have been determined by atmospheric precipitation (Table 1).

\section{Discussion}

Research performed during the ablation seasons (July-August) in the periglacial basin of the Obruchev Glacier indicates that a larger dissolved solids yield was transported during the period with snow cover than at the same time of the year but without snow cover. The melting of snow during the ablation season causes intense infiltration and outflow of water, which can dissolve and transport rock matter. This mechanism becomes limited during periods without snow cover because of an inadequate supply of water, which washes the soil as well as weathered rocks and ,in consequence, transports dissolved matter. The research data suggests that melting snow is an important factor impacting the dissolved solids yield in surface waters.

During the period with snow cover, melting snow provided large quantities of water, which was indicated by via discharge measurements at the hydrometric site. Dissolved ions become diluted, which results in lower concentrations than those detected during the period without snow cover.
The low degree of chemical weathering across the study area, resulting in a low yield of dissolved solids, is determined by the geologic structure of the parent material. The investigated area is formed of crystalline metamorphic rocks mainly consisting of silicates resistant to weathering (mica, quartz, and feldspars). Harsh local climate conditions certainly contribute to the low rate of chemical weathering in the area. A short period of non-freezing temperatures (Mangerud et al. 2008) and, thereby, long and cold winters when water is in a solid state make the dissolution of minerals difficult.

Low weathering rates are characteristic of the Polar Ural region (Lessovaia \& Polekhovsky 2009). This results in very slow changes in the soil and negligible changes in mineral composition of the soils of the Polar Urals, which is driven by the harsh local climate.

The concentration of dissolved solids in the waters of the investigated basin can be several times lower than that in periglacial basins located on the Scandinavian Peninsula (Darmody et al. 2000, Beylich et al. 2004, Zakharova et al. 2007), on Spitsbergen (Krawczyk \& Pettersson 2007), and in the Rocky Mountains (Caine 1992). In some periglacial basins featuring similar geologic structure (gneiss, granite, mica, schists) on the Scandinavian Peninsula, the concentration of $\mathrm{Na}^{+}$and $\mathrm{K}^{+}$is higher than that of $\mathrm{Ca}^{2+}$ (Beylich et al. 2004, Zakharova et al. 2007).

Thick layers of postglacial deposits from the Last Glacial Maximum (LGM) - and no older can be found across the regions just mentioned. Moraine matter is more susceptible to chemical weathering. In the Polar Urals, on the other hand, glaciers did not venture very far during the LGM (Mangerud et al. 2008). An example would be the Chernov Glacier, which borders the Obruchev Glacier from the west. The small extent of glacier resulted in a relative absence of moraine matter, which may have contributed to a lower rate of chemical weathering weathering than the materials consisting of rocks and their saprolites.

The water samples collected contained relatively large quantities of $\mathrm{Ca}^{2+}$ and $\mathrm{HCO}_{3}{ }^{-}$, despite the fact that the study area is formed of rocks containing low amounts of calcium. The $\mathrm{HCO}_{3}{ }^{-}$ ion may be the product of the dissolution of atmospheric $\mathrm{CO}_{2}$. Normally, $\mathrm{HCO}_{3}{ }^{-}$and $\mathrm{Ca}^{2+}$ ions 
in water come from the dissolution of carbonates or calcium plagioclase (Wynn et al. 2006), however, no exposed carbonate rocks were found across the study area. Moreover, calcium plagioclases most likely are absent in rocks and their saprolites.

The hydrochemical indices calculated for the water samples collected indicate that plagioclase weathering - which could be a potential source of calcium - does not contribute very much to the detected $\mathrm{Ca}^{2+}$ content. High $\mathrm{Ca}^{2+}$ concentrations may be the result of aeolic influx from areas featuring carbonate rocks in their parent material. Areas of this type are located to the west and the southwest of the study area, for example, in Paypudina Valley.

Aeolic transport of fine-grained rock matter is possible thanks to air circulation from the south, which is an observable form of circulation across the Polar Ural Mountains (Piotr Wałach, personal communication). However, the very low and negative values of the LSI index suggest that calcite dissolution must be very limited. In short, the origin of calcium in the surface water is difficult to establish based on the data available. It appears that several different factors may be responsible for the $\mathrm{Ca}^{2+}$ supply to waters.

\section{Conclusions}

1. Very low total ion content in the waters of the periglacial basin of the Obruchev Glacier (Polar Ural Mountains), determined during the ablation season (July-August), indicate that rate of chemical weathering is low.

2. Low ion content in water samples is primarily the result of geologic structure (the occurrence of weathering-resistant silicate minerals in the parent material), harsh climate conditions (low air temperatures, limiting weathering processes and decelerating dissolution of minerals), and little moraine cover from the LGM.

3. A decidedly higher dissolved solids yield is produced during periods with snow cover suggesting an importance of snow cover in chemical denudation mechanisms in periglacial basins.

\section{Acknowledgement}

Authors would like to thank Barbara Jaszczyńska and Łukasz Jelonkiewicz (Institute of Geography and Spatial Management, JU) for hydrochemical analysis of water samples; Anna Łatkiewicz (Institute of Geological Sciences, JU) for determining mineral composition of rocks and deposits by XRD; colleagues from project Polar Ural Environmental Change after Last Ice Age (PUECH) included into IV IPY for collaboration during field works. Grzegorz Zębik is acknowledged for a translation of the text.

\section{References}

Beylich A., Sandberg O., Molau U. \& Wache S., 2006. Intensity and spatio-temporal variability of fluvial sediment transfers in an Arctic-oceanic periglacial environment in northernmost Swedish Lapland (Latnjavagge catchment). Geomorphology 80(1-2): 114-130, DOI:10.1016/j. geomorph.2005.09.014.

Beylich A. Kolstrup E. Thyrsted T. \& Gintz D., 2004. Water chemistry and its diversity in relation to local factors in the Latnjavagge drainage basin, arctic-oceanic Swedish Lapland. Geomorphology 58 (1-4): 125-143, DOI:10.1016/ S0169-555X(03)00228-9.

Bolewski A., 1982. Mineralogia szczegótowa (Detailed Mineralogy). Wydawnictwa Geologiczne, Warszawa.

Brown G., 2002. Glacial meltwater hydrochemistry. Applied Geochemistry 17(7): 855-883, DOI:10.1016/S08832927(01)00123-8.

CAINE N., 1992. Spatial patterns of geochemical denudation rate in a Colorado Alpine Environment. In: J.C. Dixon, A.D. Abrahams (eds.), Periglacial Geomorphology Proceedings to the 22 ${ }^{\text {nd }}$ Annual Binghamton Symposium in Geomorphology, John Wiley and sons, Chichester: 63-88.

CAINE, N., 1979. Rock weathering rates at the soil surface in an alpine environment. Catena 6(2): 131-144, DOI:10.1016/0341-8162(79)90003-1.

Collins N., 1979. Hydrochemistry of meltwaters draining from an alpine glacier (Gornergletsher, Switzerland). Arctic and Alpine Research, 11(3): 307-324.

Darmody R.G., Thorn C.E., Harder R.L., Schlyter J.P. \& DixON J.C., 2000. Weathering implications of water chemistry in an arctic-alpine environment, northern Sweden. Geomorphology, 34(1-2): 89-100, DOI:10.1016/S0169555X(00)00002-7.

Dixon J.C., Thorn C.E. \& Darmody R.G., 1984. Chemical weathering processes on the Vantage Peak Nunatak, Juneau Icefield, southern Alaska. Physical Geography, 5: 111-131.

Hodson A., Tranter M. \& Vante G., 2000. Contemporary rates of chemical denudation and $\mathrm{CO}_{2}$ sequestration in glacier basins: an Arctic perspective. Earth Surface Processes and Landforms, 25: 1447-1471, DOI: $\quad 10.1002 / 1096.9837(200012) 25: 13<1447:: A I D-$ ESP156>3.0.CO; 2-9. 
HounsLow A.W., 1995. Water Quality Data Analysis and Interpretation. Lewis Publisher, Los Angeles.

KonONOV Y., ANANicheVA, M. \& Willis, I., 2005. High-resolution reconstruction of Polar Ural glaciers mass balance for the last millennium. Annals of Glaciology, 42: 163-170, DOI: $10.3189 / 172756405781812709$.

KrawczyK W. \& PetTersson L.-E. 2007. Chemical denudation rates and carbon dioxide drawdown in an ice-free polar karst catchment: Londonelva, Svalbard. Permafrost and Periglacial Processes 18(4): 337-350, DOI: 10.1002/ppp. 599.

Lessovaia S.N. \& Polekhovsky Yu., 2009. Mineralogical composition of shallow soils on basic and ultrabasic rocks of East Fennoscandia and of the Ural Mountains, Russia. Clays and Clay Minerals, 57(4): 476-485, DOI: 10.1346/ CCMN.2009.0570408.

Mangerud J., Gosse J., MatiouchKov A. \& Dolvik T., 2008. Glaciers in the Polar Urals, Russia, were not much larger during the Last Global Glacial Maximum than today. Quaternary Science Reviews, 27 (9-10): 1047-1057, DOI: 10.1016/j.quascirev.2008.01.015.

RAPP A., 1960. Recent development of mountain slopes in Karkevagge and surroundings, northern Scandinavia. Geografiska Annaler, 42: 71-200.

StUPNICKA E., 1978. Zarys geologii regionalnej świata. Wydawnictwa Geologiczne, Warszawa.

Tranter M., Brown G. H., Hodson A. J. \& Gurnell A. M. 1996: Hydrochemistry as an indicator of subglacial drainage system structure: A comparison of alpine and sub-polar environments. Hydrological Processes 10(4): 541-556, DOI: $\quad 10.1002 /(S I C I) 1099-1085(199604) 10: 4<541:: A I D-$ HYP391>3.0.CO; 2-9.

TROITSKY L.S., 1961. Some features of modern glaciation of Polar Urals. (Nekotoriye osobennosti sovremennogo oledeneniya Poliarnogo Urala). Glaciological Studies. (Gliatsiologicheskiye issledovaniya) 6: 70-85.

TUSHINSKIY G.K., 1963. Glaciers, snowfield, and avalanche of the Soviet Union. State Publishing House of Geographical Literature, Moscow.

Wadham J.L., Hodson A.J., Tranter M. \& Dowdeswell J.A., 1998. The hydrochemistry of meltwaters draining a polythermal-based, high arctic glacier, south Svalbard: I. The ablation season. Hydrological Processes 12(12): 1825-1849, DOI: 10.1002/(SICI)10991085(19981015)12:12<1825::AID-HYP669>3.0.CO; 2-R.

Wadham J.L., Tranter M. \& Dowdeswell J.A., 2000. Hydrochemistry of meltwaters draining a polythermal-based, high-arctic glacier, south Svalbard: II. winter and early spring. Hydrological Processes 14(10): 1767-1786, DOI: 10.1002/1099-1085(200007)14:10<1767::AID-HYP103 $>3.0 . \mathrm{CO} ; 2-\mathrm{Q}$.

WAŁACH P., 2008. The daily air temperature course in the bottom of selected glacier cirques in the Polar Ural. Problemy Klimatologii Polarnej, 18: 171-180.

WaŁach P. \& StachniK Ł., 2011. Wpływ warunków meteorologicznych na kształtowanie się odpływu i chemizmu wód w zlewni lodowca Obrucheva (Ural Polarny). Przegląd Geograficzny. (in review)

VolOSHINA A.P., 1987. Some totals of the mass balance studies of Polar Ural glaciers. Data of Glaciologic Studies 61: 44-51.

Zakharova E.A., Pokrovsky O.S., Dupré B., Gaillardet J. \& EFIMOVA L.E., 2007. Chemical weathering of silicate rocks in Karelia region and Kola peninsula, NW Russia: Assessing the effect of rock composition, wetlands and vegetation. Chemical Geology 242: 255-277, DOI: 10.1016/j. chemgeo.2007.03.018. 